\title{
Diyabetik Sıçanlarda Melatonin Uygulamasının Karaciğer, Böbrek, Mide, Pankreas ve Göz Dokularında Oksidatif Stres Üzerine Etkisi
}

\author{
Meryem ERGENÇ ${ }^{1}$, Salim ÖZENOĞLU ${ }^{1}$, İnci TURAN ${ }^{2}$, Veysel Haktan ÖZAÇMAK ${ }^{2}$, Hale SAYAN ÖZAÇMAK ${ }^{2}$ \\ ${ }^{1}$ Bülent Ecevit Üniversitesi Sağlık Bilimleri Enstitüsü, Zonguldak \\ ${ }^{2}$ Bülent Ecevit Üniversitesi Tip Fakültesi Fizyoloji Anabilim Dalı, Zonguldak
}

\begin{abstract}
ÖZET
Amaç: Oksidatif stresin diyabetik komplikasyonların gelişiminde çok önemli rol oynadığı yaygın olarak kabul edilmektedir. Böylece koruyucu tedaviler hastalığın olası yan etkilerini hafifletebilir. Bu çalışmanın amacı melatonin tedavisinin diyabetik sıçanların karaciğer, böbrek, pankreas, mide ve retinal dokularındaki oksidan ve antioksidan durumuna etkisini incelemektir.

Gereç ve Yöntemler: Erkek Wistar albino cinsi sıçanlar 4 gruba ayrıldılar: Kontrol, kontrol+melatonin, diyabetik ve diyabet+melatonin uygulanan grup. Sıçanlarda intraperitoneal (i.p) olarak tek doz streptozotosin (STZ) $(60 \mathrm{mg} / \mathrm{kg}$ ) uygulaması ile diyabet oluşturulmuştur. Melatonin $10 \mathrm{mg} / \mathrm{kg}$ dozunda günde tek doz i.p olarak 30 gün boyunca uygulanmıştır. 30 günlük tedavinin sonunda indirgenmiş glutatyon (GSH) ve malondialdehid (MDA) düzeyleri karaciğer, böbrek, pankreas, mide ve retinada ölçülmüştür.

Bulgular: Sonuçlarımız diyabetik hayvanların dokularında MDA düzeylerinin arttığını ve GSH seviyelerinin azaldığını göstermiştir. Melatonin uygulaması karaciğer dışındaki dokularda MDA düzeylerini anlamlı olarak düşürmüştür. Melatonin tedavisi diyabet grubuna göre karşılaştııldığında GSH düzeylerinde pankreas ve mide dışındaki dokularda artış bulunmuştur.

Sonuç: Bu çalışmada sunulan sonuçlar, diyabete, diyabetik komplikasyonların başlıca nedeni olarak kabul edilen oksidatif stresin eşlik ettiği ortak görüşüyle uyumludur. Sonuçlarımız melatoninin diyabette artan oksidatif stres üzerinde iyileştirici etkisi ile kullanılabileceğini göstermektedir.
\end{abstract}

Anahtar Sözcükler: Diabetes mellitüs, Melatonin, Oksidatif stres, Glutatyon.

\section{The Effect of Melatonin Administration in Diabetic Rats on Oxidative Stress in Liver, Kidney, Stomach, Pancreas and Eye Tissues}

\begin{abstract}
Aim: It is commonly accepted that oxidative stress plays a crucial role in the development of diabetic complication. Thus, preventive therapy can alleviate the possible side effects of the disease. The aim of the present study was to investigate the effect of melatonin administration on the oxidant and antioxidant system in the liver, kidney, pancreas, stomach and retinal tissues of diabetic rats.

Material and Methods: Male Wistar albino rats were randomly divided into 4 groups: control; control+Melatonin treatment; diabetic; diabetic+melatonin treatment. Rats were injected with a single intraperitoneal (i.p) injection of streptozotocin (STZ) (60 mg/kg) to induce diabetes mellitus. Melatonin ( $10 \mathrm{mg} / \mathrm{kg}$ ) was given daily by i.p injection for 30 days. After 30 days of treatment, the contents of reduced glutathione (GSH) and malondialdehyde (MDA) in liver, kidney, pancreas, stomach and retina were assayed.

Results: Our results showed that diabetic rats exhibited significant decreases in GSH level and exhibited a high level of MDA in tissues. Melatonin treatment significantly reduced the elevated MDA level all tissues except liver tissue. GSH levels were found to increase in all tissues except pancreas and stomach after melatonin treatment compared diabetes group.

Conclusion: The results presented in this study are in agreement with the common view that diabetes is accompanied by oxidative stress, which is regarded as the main cause of diabetic complications. Our results suggests that melatonin could be used for its ameliorative effect against oxidative stress in diabetes.
\end{abstract}

Key Words: Diabetes mellitus, Melatonin, Oxidative stress, Glutathione.

DOI: $10.25048 /$ tjdo.2017.19 


\section{GİRIS}

Diabetes Mellitüs (DM) ile ortaya çıkan yüksek kan şekeri proteinlerin glikozilasyonu ve glukoz oksidasyonu ile serbest oksijen radikallerinin (SOR) oluşumuna yol açarak oksidatif stresin gelişimine neden olur. Oksidatif stres diyabetik komplikasyonların temel nedeni olarak kabul edilmekte ve diyabetle birlikte gözlenen böbrek yetmezliği, körlük, kardiovasküler hastalıklar ve kanseri içeren ciddi sağlık problemlerinin patogenezinden sorumlu tutulmaktadır. Diyabetik deney hayvanlarında ortaya çıkan oksidatif stresin glukoz otooksidasyonu, lipid peroksidasyonu, protein glikasyonu ve antioksidan enzimlerdeki azalmış aktivite sonucu ortaya çıktığı bildirilmektedir $(1,2,3)$. Anormal olarak yüksek seviyedeki SOR ve antioksidan savunma mekanizmasındaki azalma hücresel organellerin hasarı, lipid peroksidasyonunda artış ve insülin direncinin gelişimi ile sonuçlanmaktadır $(4,5)$.

Hiperglisemi ile oluşan oksidatif stres ve inflamatuar cevap hepatosellüler hasar oluşturucu bir faktördür. SOR inflamatuar mediatörlerin salınımına neden olarak adezyon moleküllerinin yapımına ve lökosit infiltrasyonuna yol açar. Bundan başka SOR hepatositlerde apoptoz ile karaciğer dokusunda harabiyete neden olur. İnsülin tedavisi gören diyabetik hastalarda bile karaciğer hücre sayısı, büyümesi ve ölümünde değişiklikler gözlenmektedir (3).

DM dünya genelinde kronik böbrek hastalıklarının en yaygın sebebidir. Diyabetik nefropati Tip 1 ve 2 DM hastalarının \%30-40'ında gözlenmektedir (6). Diyabetik nefropati son dönem böbrek yetmezliğine neden olmaktadır (7). Diyabetik nefropati glomeruloskleroz, aşırı ekstrasellüler matriks birikimi, glomerular hipertrofi ve bazal membran kalınlaşması ile karakterizedir. Çalışmalar yüksek glukoz seviyesinin SOR yapımına neden olarak proksimal tübüler fonksiyonu inhibe ettiği ve podositlerde apoptoza yol açtı̆̆ını göstermiştir (8).

Sindirim ile ilgili problemler özellikle gastroparezis diyabetik hastalarda sıklıkla gözlenmektedir. Gastroparezis diyabetik hastaların \%30-50'sinde gözlenmektedir. Bu durumun gelişiminde hipergliseminin tetiklediği enterik sinir sistemi disfonksiyonu, otonomik nöropati ve oksidatif stres rol oynamaktadır (5).

Diyabetik retinopati DM'in en ciddi mikrovasküler komplikasyonlarından biridir ve gelişmekte olan ülkelerde görme azlığı ve körlüğe neden olmaktadır. DM'in deneysel çalışmalarında diyabetin retinanın nöronal ve vasküler yapılarda harabiyete neden olduğu bildirilmektedir. Retinal hasarın moleküler mekanizmaları arasında artmıș oksidatif stres, protein oksidasyonu ve oksidatif DNA hasarı yer almaktadır. Diyabet retinada endojen bir antioksidant olan glutatyon miktarında azalmaya neden olmaktadır ve bu da retinayı hasara karşı daha duyarlı hale getirmektedir $(9,10)$.

Melatonin primer olarak pineal bezden salgılanan bir hormondur. Melatoninin oldukça güçlü antioksidant ve antiinflamatuar etkileri bulunmaktadır. Daha önceki çalışmalarda melatoninin pankreas, böbrek, karaciğer, nöral ve korneal dokularda hasarı azaltarak diyabetin komplikasyonlarına karşı koruyucu olduğu gösterilmiştir (11). Diyabetik hasta ve diyabetik sıçanların serumlarında melatonin düzeylerinin ilginç olarak düşük olduğu saptanmıştır (7). Diyabette endojen antioksidan koruma sisteminde bozukluklar nedeniyle diyabetin tedavisinde eksojen antioksidanların uygulanması üzerine odaklanılmaktadır. Melatoninin streptozotosin (STZ) ile oluşturulan diyabetik sıçanlarda bozulmuş antioksidan sistemi normale döndürebildiği bulunmuştur $(6,7,11,12)$.

SOR yapımının artması ile oksidatif stresin oluşması diyabetik hastalarda anemi, hepatopati, nefropati, retinopati ve vasküler hastalıklar gibi bazı komplikasyonlar sıklıkla gözlenmektedir. $\mathrm{Bu}$ nedenle antioksidan bazlı tedavilerin diyabetin oksidatif stres kaynaklı komplikasyonlarının engellenmesinde etkili olabileceği vurgulanmaktadır (12). Bu çalışmanın amacı STZ ile deneysel diyabet oluşturulmuş sıçanlarda diyabetik komplikasyonların gözlendiği karaciğer, böbrek, mide, pankreas ve retina dokularında oksidatif stres ve antioksidan durumu üzerine melatonin uygulamasının etkilerinin incelenmesidir.

\section{GEREC ve YÖNTEM}

Bu çalışma Bülent Ecevit Üniversitesi Deney Etik Kurul kararı ile Deney Hayvanları Ünitesinden temin edilen ağırlıkları 300-350 g olan 40 adet erkek Wistar albino cinsi sıçan kullanılarak yapılmıştır. Sıçanlar 12 saat gece ve gündüz 12 saat ş̧ık olacak şekilde standart kafeslerde ve sıçan yemi ile beslenerek $21^{\circ} \mathrm{C}$ isıda barındırıldılar.

Deney hayvanlarında diyabet oluşturmak için $60 \mathrm{mg} / \mathrm{kg}$ dozunda STZ (Sigma Chemical Co.,St. Louis, MO, ABD) tek doz olarak intraperitoneal (i.p) olarak uygulanmıştır ( $\mathrm{pH}$ 4,5 Sitrat tamponu içinde)(11). STZ uygulamasından 3 gün sonra açlık kan şekeri düzeyleri kuyruk veninden alınan kan örnekleri ile ölçülmüștür. Kan şekeri düzeyinin $250 \mathrm{mg} / \mathrm{dL}$ olması diyabet olarak kabul edilmiştir.

Çalışmada denekler her grupta 10 hayvan olacak şekilde 4 gruba ayrild:

1. Normoglisemik kontrol grubu (n:10): Bu gruptaki deney hayvanlarına deney süresinde diğer deney gruplarıyla aynı miktarda i.p serum fizyolojik (SF) uygulaması yapılmıştır.

2. Normoglisemik kontrol +melatonin grubu (n:10). Bu gruptaki deneklere melatonin uygulaması yapılmıştır. 
3. Diyabet+SF (n:10): Deneklerde diyabet oluşturulduktan sonra SF uygulaması yapılmıştır.

4. Diyabet+Melatonin uygulanan grup (n:10): Diyabet oluşturulduktan sonra melatonin uygulaması yapılan grup. Melatonin (Sigma Chemical Co.,St. Louis, $\mathrm{MO}, \mathrm{ABD}$ ) diyabet oluşturulduktan sonra $10 \mathrm{mg} /$ $\mathrm{kg}$ dozunda i.p olarak günde tek doz şeklinde 30 gün boyunca uygulanmıştır (11). 30 günlük sürenin sonunda yüksek doz anestezi ile feda edilen hayvanların karaciğer, böbrek, mide, pankreas ve retina dokuları alınarak lipid peroksidasyonun bir göstergesi olarak malondialdehid(MDA) ve endojen bir antioksidan olan indirgenmiş glutatyon (GSH) düzeyleri biyokimyasal olarak ölçülmüştür.

Lipid peroksidasyonunun göstergesi olan MDA seviyesi Casini ve ark.'nın metodu esas alınarak çalışıldı (13). Major endojen antioksidan olan GSH seviyeleri Aykac ve ark.'nın yöntemine göre ölçüldü(14).

İstatistiksel analiz: Verilerin değerlendirilmesi SPSS 22 istatistik paket programı kullanılarak yapılmıştır. Sayısal değerler ortalama \pm standart hata (SE) olarak verilmiştir. Gruplararası farklılıklar Kruskal Wallis testi ile değerlendirlmiştir. Grup içindeki anlamlılık ise Bonferroni testi ile karşılaştırılmıştır. P’nin $<0.05$ olduğu değerler istatistiksel olarak anlamlı olarak kabul edilmiştir.

\section{BULGULAR}

Karaciğer dokusu MDA ve GSH düzeyleri Şekil 1'de gösterilmiştir. Karaciğer dokusu MDA düzeyleri STZ ile diyabet oluşturulan sıçanlarda kontrol grubuna göre istatistiksel olarak anlamlı yüksek bulunmuştur $(\mathrm{p}<0,05)$. Ancak melatonin uygulamasının karaciğer dokusunda MDA düzeylerini azaltmada etkili olmadığı gözlenmiştir ( $p>0,05)$. GSH düzeylerinde ise diyabet grubunda belirgin azalma gözlenirken bu azalmanın melatonin uygulaması ile korunduğu saptanmıştır $(\mathrm{p}<0,05)$.

Böbrek dokusunda MDA düzeylerinin diyabetik hayvanlarda kontrol ve melatonin+diyabet grubuna göre belirgin olarak yükseldiği saptanmıştır $(\mathrm{p}<0,05)$. Melatoninin diyabetle ortaya çıan oksidatif stresi azaltmada etkili olduğu gözlenmektedir. Ayrıca melatonin uygulanan diyabet grubunda GSH düzeylerinde kontrol ve diyabet gruplarına göre istatistiksel olarak anlamlı artışın olduğu bulunmuştur $(\mathrm{p}<0,05)$ (Şekil 2).

Retinal dokuda MDA düzeylerinin diyabet grubunda kontrol gruplarına göre arttığı ve bu artışın melatonin uygulaması ile kontrol grubu seviyelerine indirilebildiği saptanmıştır. GSH seviyesinin melatonin uygulaması sonrasinda istatistiksel olarak anlamlı şekilde arttığı görülmüştür $(\mathrm{p}<0,05)$ (Şekil 3).

Pankreas dokusu MDA değerleri incelendiğinde diyabet + melatonin grubunda diyabet grubuna göre belirgin azalma tespit edilmiştir $(\mathrm{p}<0,05)$. Pankreas dokusu GSH düzeyinde melatonin uygulaması sonrasında istatistiksel olarak anlamlı bir değişim saptanmamıştır ( $\mathrm{p}>0,05)$ (Şekil 4).

Mide dokusu MDA düzeyleri diyabet sonrasında anlamlı olarak artmıştır $(\mathrm{p}<0,05)$. Mide dokusu MDA ve GSH düzeylerinde melatonin uygulanan grup hayvanlarında diyabetli gruba göre anlamlı azalma belirlenmiştir $(\mathrm{p}<0,05)$ (Şekil 5).
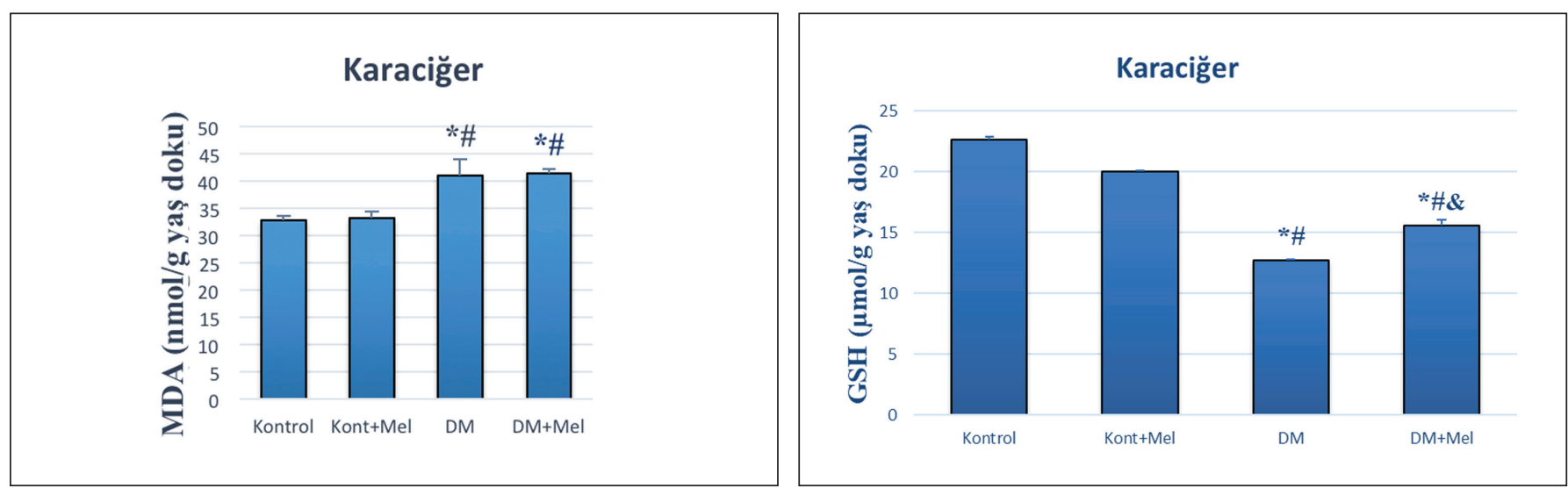

Şekil 1: Karaciğer dokusu MDA ve GSH değerleri. Diyabet sonrasında karaciğer dokusu MDA düzeylerinde kontrol gruplarına göre anlamlı artış tespit edilmiştir. Melatonin uygulamasının karaciğer MDA düzeylerini azaltmada etkili olmadığı saptanmıştır. GSH düzeylerinde ise diyabet gruplarında kontrol gruplarına göre istatistiksel olarak anlamlı düşüş tespit edilmiştir. Melatonin uygulamasının diyabetli hayvanlarda GSH düzeylerindeki azalmayı engellemede etkili bulunmuştur. "Kontrol, " Kontrol+Melatonin, \& Diyabet+SF grubuna göre anlamlı farklılığı göstermektedir. $\mathrm{P}<0,05$ anlamlı kabul edilmiştir. Sonuçlar ortalama \pm SE olarak verilmektedir. 


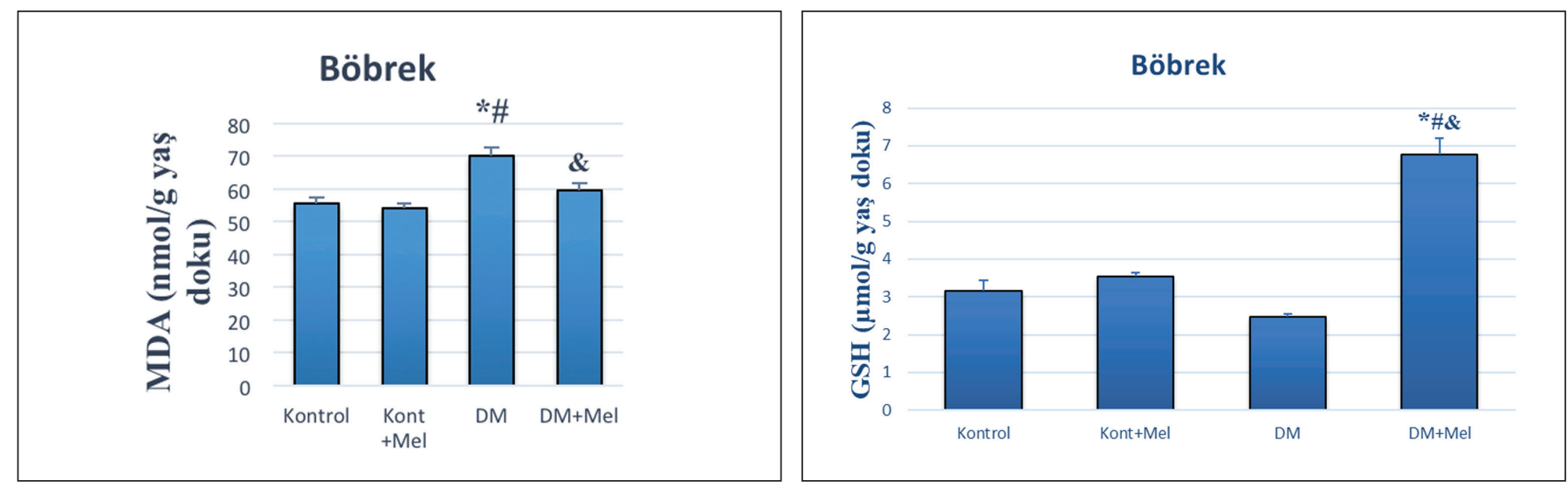

Şekil 2: Böbrek dokusu MDA ve GSH değerleri. Melatonin böbrek dokusunda diyabet ile artan oksidatif stresi azaltmıştır. Melatonin uygulaması sonrasında diyabetik hayvanlarda böbrek dokusu GSH düzeylerinde diğer gruplara göre anlamlı artış gözlenmiştir. "Kontrole göre, ” Kontrol+Melatonin grubuna göre, \& Diyabet+SF grubuna göre anlamlı farklılığı göstermektedir. $\mathrm{P}<0,05$ anlamlı kabul edilmiştir. Sonuçlar ortalama \pm SE olarak verilmektedir.
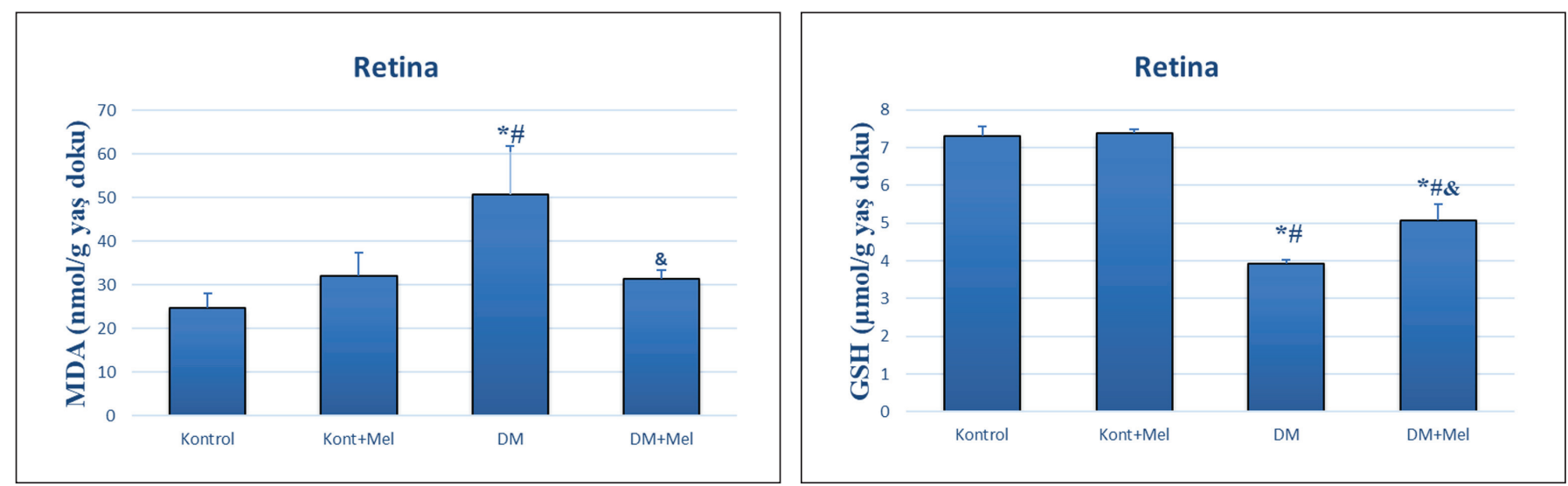

Şekil 3: Retina dokusu MDA ve GSH değerleri. Melatonin retinada oksidatif stresi azaltmada ve GSH düzeylerinin yükseltilmesinde

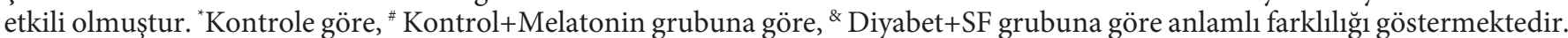
$\mathrm{P}<0,05$ anlamlı kabul edilmiștir. Sonuçlar ortalama \pm SE olarak verilmektedir.
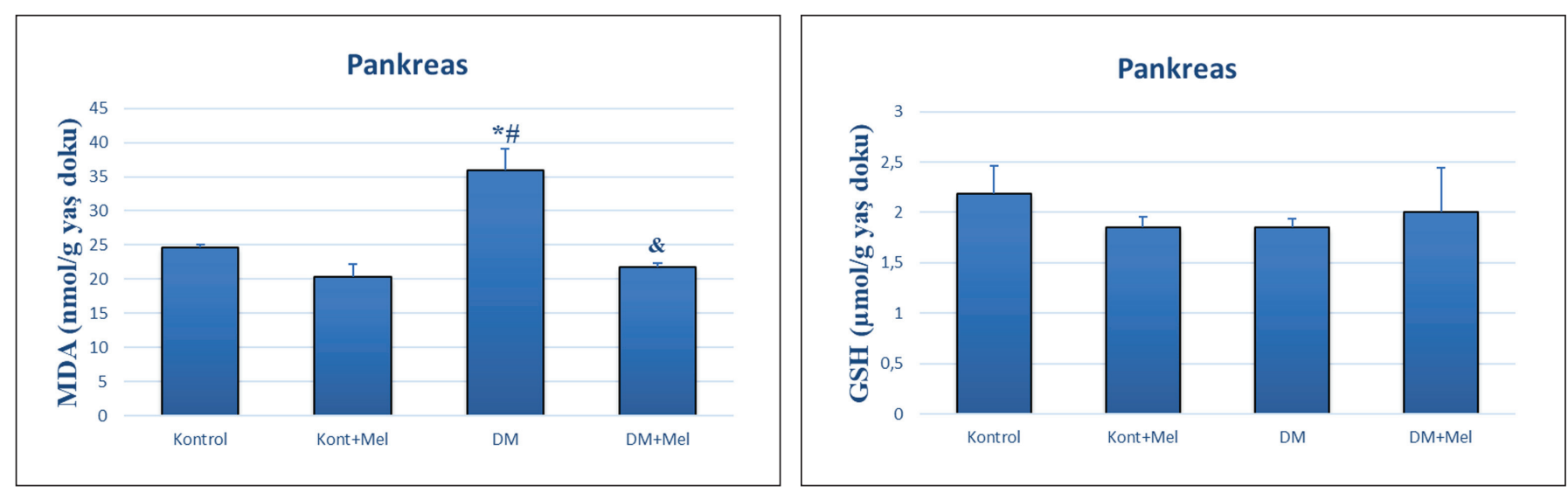

Şekil 4: Pankreas dokusu MDA ve GSH değerleri. MDA düzeyleri melatonin tedavisi sonrasında anlamlı olarak azalmıştır. GSH düzeylerinde istatistiksel olarak anlamlı değişiklik saptanmamıştır. *Kontrole göre, \# Kontrol+Melatonin grubuna göre, \& Diyabet+SF grubuna göre anlamlı farklılığı göstermektedir. $\mathrm{P}<0,05$ anlamlı kabul edilmiştir. Sonuçlar ortalama \pm SE olarak verilmektedir. 

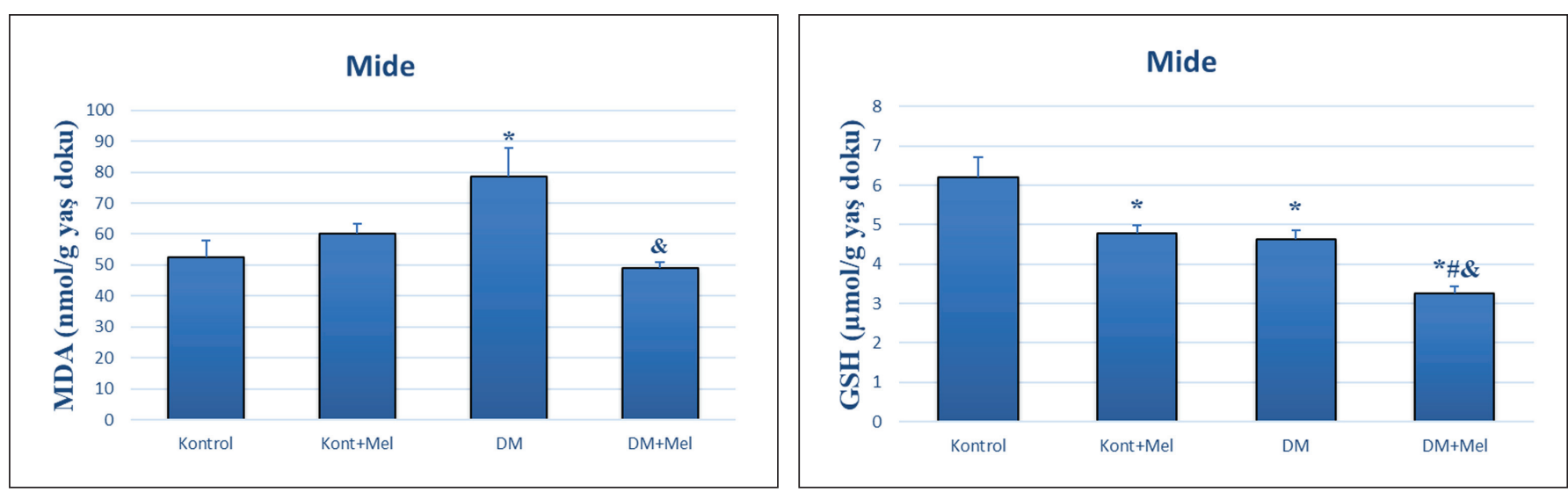

Şekil 5: Mide dokusu MDA ve GSH değerleri. MDA düzeyleri melatonin uygulanan grupta Diyabet+SF grubuna göre anlamlı olarak azalmıștır. Diyabetle birlikte mide dokusu GSH düzeyleri kontrol grubuna göre anlamlı azalırken, melatonin uygulaması bu azalmayı engellemede etkili görülmemiştir. Diyabet+melatonin grubunda GSH düzeyleri Diyabet+SF grubuna göre istatistiksel olarak anlamlı düzeyde düşük bulunmuştur. "Kontrole göre, * Kontrol+Melatonin grubuna göre, \& Diyabet+SF grubuna göre anlamlı farklılığı göstermektedir. $\mathrm{P}<0,05$ anlamlı kabul edilmiştir. Sonuçlar ortalama $\pm S E$ olarak verilmektedir.

\section{TARTIŞMA}

Çalışmada elde edilen sonuçlara göre DM'ün karaciğer, böbrek, pankreas, mide retina dokularında MDA seviyelerinde artışa neden olduğu, buna karşın endojen antioksidan olan GSH düzeylerinde azalmaya neden olduğu gözlenmiştir. Melatonin tedavisi sonrasında dokulardaki lipid peroksidasyonu seviyesinde azalmalar gözlenirken, GSH seviyelerinin ise kontrol değerleri seviyesinde korunduğu saptanmıştır.

Literatür bilgileri incelendiğinde STZ ile oluşturulan diyabetik sıçanlarda ve tip 1 ve tip 2 diyabet hastalarında SOR üretiminin hızlandığ stres artışı ile oluşan lipid peroksidasyonu seviyesindeki artışla birlikte glutatyon homeostazisinde bozulmalar da saptanmaktadır $(15,16)$. Redoks durumundaki bu değişiklikler STZ uygulanan sıçan ve her iki tip diyabet hastalarının eritrositlerinde de gözlenmiștir (17). Melatonin uygulamasının ise diyabetle ortaya çlkan glutatyon homeostazisi bozukluklarını korumada etkili olduğu gösterilmiştir. Melatonin uygulaması sonrasında diyabetik hayvanlarda GSH seviyesinde artış böbrek, karaciğer, beyin, kalp dokularında ve plazmada gösterilmiştir(18,19,20).

Melatonin pineal bez, retina ve diğer dokulardan ritmik olarak karanlık dönemde salınan bir indoleamiddir. Melatonin hidroksil radikali, superoksit radikali ve peroksinitrit gibi SOR türevlerini olarak ortadan kaldırarak direkt antioksidan etki gösterirken, endojen antioksidan enzimlerin yapımını artırarak indirekt olarak antioksidan etki de göstermektedir (21).

Çeşitli çalışmalarda DM'ün karaciğer dokusunda hepatosit dejenerasyonu, inflamasyon, fibrozis gibi histopatolojik değişikliklere neden olduğu gösterilmiştir(22). Ayrıcakronik hiperglisemi ile artan SOR ve inflamatuar cevap, diyabetle oluşan karaciğer değişikliklerinden sorumlu tutulmaktadır (3). Elbe ve ark. (2015) diyabetle karaciğer dokusunda MDA düzeylerinin arttığını, GSH düzeylerinin azaldığını ve bu değişikliklerin melatonin ile kontrol düzeylerine getirildiğini saptamıșlardır (22). Bizim çalıșmamızda da literatürdeki bilgilere benzer şekilde diyabet sonucunda MDA düzeylerinin karaciğer dokusunda arttığı ve GSH düzeylerinde azaldığı gözlendi. Ancak melatonin tedavisi sonrasında MDA düzeylerinde istatistiksel olarak anlamlı bir azalma olmazken, GSH düzeylerinin diyabet+SF grubuna göre anlamlı olarak arttığı saptandı. GSH düzeylerindeki bu değişim literatürle uyumludur $(22,25)$. Bizim çalışmamızda diyabetik sıçanlarda melatonin uygulamasının lipid peroksidasyonu üzerine etkili olmaması çeşitli nedenlerden dolayı olabilir. Bunlar arasında melatonin uygulamalarının bazı çalışmalarda 8 haftalık süre ile uygulanması (25) veya yüksek dozlarda uygulanmasının (22) etkili olabileceğini düşünmekteyiz.

Çalışmamızda böbrek dokusu MDA düzeylerinin diyabetik sıçanlarda arttığı ve bu artıșın melatonin uygulaması ile azaldığı tespit edilmiștir. Ayrıca böbrek dokusu GSH düzeyleri melatonin uygulanan diyabetik sıçanlarda belirgin olarak yüksek olarak bulunmuştur. Bu sonuçlar literatürdeki diğer çalışmalarla benzerlik göstererek melatoninin diyabet ile ortaya çıkan oksidatif stresi böbrek dokusunda azalttı̆̆ 1 ve GSH homeostazisini düzenlediğini ortaya koymaktadır $(26,27)$.

Retina melatonin sentezinin olduğu diğer bir dokudur. Diyabetik sıçanlarda retinal melatonin sentezinin azaldığı gösterilmiştir $(28,29)$. STZ ile oluşturulan diyabet modelinde melatoninin retinal histopatolojik değișiklikleri ve apoptotik hücre ölümünü azaltabildiği bildirilmektedir 
(30). Çalışmamızda da melatoninin literatürle uyumlu olarak retinal dokuda oksidatif stresi azaltmada etkili olduğu görülmüştür $(11,28)$.

STZ içeriğindeki nitrozüre nedeniyle pankreas $\beta$ hücreleri üzerine toksik etki göstermektedir. STZ pankreas $\beta$ hücresinde NAD seviyesinde azalma ile hücre içi SOR yapımını artırarak apoptozu tetikler (31). Yavuz ve ark. (2003) melatonin pankreas $\beta$ hücresinde oksidatif stresi azaltmada etkili olduğunu göstermişlerdir (32).

Daha önceki çalıșmalara benzer olarak diyabetle birlikte mide dokusu MDA düzeylerinde artış saptanmıștır (33). Melatonin tedavisi bu artışı engellemede etkili olmuştur. Pradeepkumar ve ark. (2011) melatoninin diyabetik sıçanlarda ülser oluşumuna karşı midede koruyucu etkili olduğunu göstermişlerdir (34). GSH düzeyleri üzerine melatoninin etkili olmadığı gözlenmektedir.

Diyabetik hastalarda ve diyabetik hayvanlarda serum ve pineal bez melatonin düzeyleri azalmaktadır bu da günlük ritim desenkronizasyonuna ve dokuların antioksidan kapasitesinin azalmasına neden olmaktadır. Ayrıca diyabetle oluşan GSH azalması oksidatif stresi daha da artırmaktadır. Böylece diyabetle oluşan komplikasyonlara yatkınlığın artabildiği bildirilmektedir (35). Bu çalışmadan elde edilen sonuçlar melatoninin diyabetik komplikasyonların oluştuğu karaciğer, retina, böbrek gibi dokularda özellikle antioksidan özelliği ile oksidatif stresi azaltmada etkili olduğunu göstermiştir. Bu nedenle melatoninin diyabetin komplikasyonlarının engellenmesinde etkili bir tedavi ajanı olabileceğini düşünmekteyiz. Çalışmadan elde edilen sonuçların desteklenmesi için daha ileri araştırmaların yapılmasina gereksinim vardır.

\section{KAYNAKLAR}

1. Sheweita SA, Mashaly S, Newairy AA, Abdou HM, Eweda SM. Changes in Oxidative Stress and Antioxidant Enzyme Activities in Streptozotocin-Induced Diabetes Mellitus in Rats: Role of Alhagi maurorum Extracts. Oxid Med Cell Longev. 2016; 2016:1-8 5264064.

2. Giugliano D, Ceriello A, Paolisso G. Oxidative stress and diabetic vascular complications. Diabetes Care. 1996; 19: 257267.

3. Abdulmonim A Alqasim, Essam Eldin M Noureldin, Sami H Hammadi, Ghada E Esheba. Effect of melatonin versus vitamin D as antioxidant and Hepatoprotective agents in STZinduced diabetic rats. J. Diabetes Metab. Disord. 2017; 16: 41.

4. Yilmaz-Ozden T, Kurt-Sirin O, Tunali S, Akev N, Can A, Yanardag R. Ameliorative effect of vanadium on oxidative stress in stomach tissue of diabetic rats. Bosn. J. Basic Med. Sci. 2014; 14: 105-109.
5. Xu L, Li Z, Guo F. Curcumin improves expression of ghrelin through attenuating oxidative stress in gastric tissues of streptozotocin-induced diabetic gastroparesis rats. Eur. J. Pharmacol. 2013; 718: 219-225.

6. Onk D, Onk OA, Turkmen K, Erol HS, Ayazoglu TA, Keles ON, Halici M, Topal E. Melatonin Attenuates Contrast-Induced Nephropathy in Diabetic Rats: The Role of Interleukin-33 and Oxidative Stress. Mediators Inflamm. 2016; 2016: 1-20.

7. Derlacz RA, Sliwinska M, Piekutowska A, Winiarska K, Drozak J, Bryla J. Melatonin is more effective than taurine and 5-hydroxytryptophan against hyperglycemia-induced kidneycortex tubules injury. J. Pineal Res. 2007; 42: 203-209.

8. Zhang J, Yang S, Li H, Chen F, Shi J. Naringin ameliorates diabetic nephropathy by inhibiting NADPH oxidase 4. Eur. J. Pharmacol. 2017; 804: 1-6.

9. Al-Dosari DI, Ahmed MM, Al-Rejaie SS, Alhomida AS, Ola MS. Flavonoid Naringenin Attenuates Oxidative Stress, Apoptosis and Improves Neurotrophic Effects in the Diabetic Rat Retina. Nutrients. 2017; 9: E1161.

10. Kumar B, Gupta SK, Nag TC, Srivastava S, Saxena R, Jha KA, Srinivasan BP. Retinal neuroprotective effects of quercetin in streptozotocin-induced diabetic rats. Exp Eye Res. 2014; 125 : 193-202.

11. Jiang T, Chang Q, Cai J, Fan J, Zhang X, Xu G. Protective Effects of Melatonin on Retinal Inflammation and Oxidative Stress in Experimental Diabetic Retinopathy. Oxid. Med. Cell Longev. 2016; 2016: 1-13.

12. Allagui MS, Feriani A, Bouoni Z, Alimi H, Murat JC, El Feki A. Protective effects of vitamins ( $\mathrm{C}$ and $\mathrm{E}$ ) and melatonin coadministration on hematological and hepatic functions and oxidative stress in alloxan-induced diabetic rats. J Physiol. Biochem. 2014; 70: 713-723.

13. Casini A, Ferrali M, Pampella A, Maellaro E, Comporti M. Lipid peroxidation and cellular damage in extrahepatic tissues of bromobenzene-intoxicated mice. Am J Pathol. 1986; 123: 520-531.

14. Aykac G, Uysal M, Yalan AS, et al. The effects of chronic ethanol injection on hepatic lipid peroxide, glutathione, glutathione peroxidase and glutathione transferase in rats. Toxicology 1985; 36:71-76.

15. Montilla PL, Vargas JF, Tunez IF, Muñoz de Agueda MC, Valdelvira ME, Cabrera ES. Oxidative stress in diabetic rats induced by streptozotocin: protective effects of melatonin. J Pineal Res. 1998; 25: 94-100.

16. Dominguez C, Ruiz E, Gussinye M, Carrascosa A. Oxidative stress at onset and in early stages of type 1 diabetes in children and adolescents. Diabetes Care 1998; 21: 1736-1742.

17. Meral I, Yener Z, Kahraman T, Mert N. Effect of Nigella sativa on glucose concentration, lipid peroxidation, anti-oxidant defence system and liver damage in experimentally-induced diabetic rabbits. J Vet Med A Physiol Pathol Clin Med. 2001; 48: 593-599. 
18. Aksoy N, Vural H, Sabuncu T, Aksoy S. Effects of melatonin on oxidative-antioxidative status of tissues in streptozotocininduced diabetic rats. Cell Biochem Funct. 2003; 21: 121-125.

19. Baydas G, Reiter RJ, Yasar A, Tuzcu M, Akdemir I, Nedzvetskii VS. Melatonin reduces glial reactivity in the hippocampus, cortex, and cerebellum of streptozotocin-induced diabetic rats. Free Radic Biol Med. 2003; 35: 797-804.

20. Winiarska K, Fraczyk T, Malinska D, Drozak J, Bryla J. Melatonin attenuates diabetes-induced oxidative stress in rabbits. J Pineal Res. 2006; 40: 168-176.

21. Gobbo MG, Costa CF, Silva DG, de Almeida EA, Góes RM. Effect of Melatonin Intake on Oxidative Stress Biomarkers in Male Reproductive Organs of Rats under Experimental Diabetes. Oxid Med Cell Longev. 2015; 2015: 1-11

22. Elbe H, Esrefoglu M, Vardi N, Taslidere E, Ozerol E, Tanbek K. Melatonin, quercetin and resveratrol attenuates oxidative hepatocellular injury in streptozotocin-induced diabetic rats. Hum Exp Toxicol. 2015; 34: 859-868.

23. Yanardag R, Ozsoy-Sacan O, Bolkent S, Orak H, KarabulutBulan O. Protective effects of metformin treatment on the liver injury of streptozotocin-diabetic rats. Human Exp Toxicol. 2005; 24: 129

24. Guven A, Yavuz O, Cam M, Ercan F, Bukan N, Comunoglu C, Gokce F. Effects of melatonin on streptozotocin-induced diabetic liver injury in rats. Acta Histochemica. 2006; 108: 85-93.

25. Korkmaz GG, Uzun H, Cakatay U, Aydin S. Melatonin ameliorates oxidative damage in hyperglycemia-induced liver injury. Clin Invest Med. 2012; 35: 370-377.

26. Cam M, Yavuz O, Guven A, Ercan F, Bukan N, Ustundag N. Protective effects of chronic melatonin treatment against renal injury in streptozotocin-induced diabetic rats. J Pineal Res. 2003; 35: 212-220

27. Oktem F, Ozguner F, Yilmaz HR, Uz E, Dündar B. Melatonin reduces urinary excretion of $\mathrm{N}$-acetyl-beta-D-glucosaminidase, albumin and renal oxidative markers in diabetic rats. Clin Exp Pharmacol Physiol. 2006; 33: 95-101.
28. Tosini G, Menaker M. The clock in the mouse retina: melatonin synthesis and photoreceptor degeneration. Brain Research. 1998; 789: 221-228.

29. do Carmo Buonfiglio D, Peliciari-Garcia RA, do Amaral FG, Peres R, Nogueira TC, Afeche SC, Cipolla-Neto J. Early-stage retinal melatonin synthesis impairment in streptozotocininduced diabetic wistar rats. Investigative Ophthalmology and Visual Science. 2011; 52: 7416-7422.

30. Gürpinar T, Ekerbiçer N, Uysal N, Barut T, Tarakçi F, Tuglu MI. The effects of the melatonin treatment on the oxidative stress and apoptosis in diabetic eye and brain. The Scientific World Journal. 2012; 2012: 1-5.

31. Bathina S, Srinivas N, Das UN. Streptozotocin produces oxidative stress, inflammation and decreases BDNF concentrations to induce apoptosis of RIN5F cells and type 2 diabetes mellitus in Wistar rats. Biochem Biophys Res Commun. 2017; 486: 406-413.

32. Yavuz O, Cam M, Bukan N, Guven A, Silan F. Protective effect of melatonin on beta-cell damage in streptozotocin-induced diabetes in rats. Acta Histochem. 2003; 105: 261-266.

33. Coskun ZM, Sacan O, Karatug A, Turk N, Yanardag R, Bolkent S, Bolkent S. Regulation of oxidative stress and somatostatin, cholecysto-kinin, apelin gene expressions by ghrelin in stomach of newborn diabetic rats. Acta Histochem. 2013; 115: 740-747.

34. Pradeepkumar Singh L, Vivek Sharma A, Swarnakar S. Upregulation of collagenase-1 and -3 in indomethacininduced gastric ulcer in diabetic rats: role of melatonin. J Pineal Res. 2011; 51(1):61-74.

35. Grigorov I, Bogojević D, Jovanović S, Petrović A, IvanovićMatić S, Zolotarevski L, Poznanović G, Martinović V. Hepatoprotective effects of melatonin against pronecrotic cellular events in streptozotocin-induced diabetic rats. J Physiol Biochem. 2014; 70: 441-450. 
